Original article

\title{
Spatio-temporal land cover dynamics and emerging landscape patterns in western part of Lagos State, Nigeria
}

Jerry N. Obiefuna ${ }^{1}$, Chukwuma J. Okolie ${ }^{2 *}$, Ajiri O. Atagbaza², Peter C. Nwilo², Folayele. 0. Akindeju ${ }^{3}$

${ }^{1}$ Department of Architecture, Faculty of Environmental Sciences, Enugu State University of Science and Technology, Enugu, Nigeria

2Department of Surveying and Geoinformatics, Faculty of Engineering, University of Lagos, Lagos, Nigeria ${ }^{3}$ Department of Urban and Regional Planning, Faculty of Environmental Sciences, University of Lagos, Lagos, Nigeria E-mail address (*corresponding author): cokolie@unilag.edu.ng

ORCID iD: Jerry N. Obiefuna: https://orcid.org/0000-0002-1083-1735; Chukwuma J. Okolie: https://orcid.org/0000-0003-45427051; Ajiri O. Atagbaza: https://orcid.org/0000-0002-3123-6636; Peter C. Nwilo: https://orcid.org/0000-0002-3912-9544; Folayele O. Akindeju: https://orcid.org/0000-0002-4375-7295

\begin{abstract}
Lagos State, which is home to Lagos metropolis and the eighteenth largest urban agglomeration in 2018 in the world, has been characterized by rapid urbanization. An earlier study of the eastern segment of the state revealed dramatic urban growth in previously rural local councils where it replaced mostly ecological assets. For a statewide view of the landscape pattern changes, this study examined the western segment of the state to characterize the magnitude and trend of these changes. This was done with Landsat images for 1984, 2006 and 2015 along with ENVI 5.0 software and FRAGSTATS v.4.2 spatial pattern analysis program. Results show that cumulatively, the ecological assets, which comprised $75 \%$ of the area in 1984, have been whittled down to about $34 \%$ by 2015 having been lost through urban development. At the council level in 2015, the highest growth areas, in decreasing order of magnitude, were Alimosho, Badagry, Ojo and Amuwo Odofin local government areas. Both class and landscape-level metrics confirmed the dominance and fragmentation of the resultant landscape in 2015 by urban development. In 1984, vegetation dominated the landscape at $55 \%$ coverage and was the largest feature with the highest area-weighted contiguity or connectedness index. Thirty-one years later in 2015, built-up areas were the dominant patch with 54\% coverage and the highest contiguity and area-weighted contiguity index, higher than vegetation. These findings have narrowed the information gap about the spatial and temporal changes in the ecological assets of the western segment of Lagos State as a result of rapid urban expansion.
\end{abstract}

KEY WORDS: Landsat data, rapid urbanization, urban sprawl, land cover change, landscape metrics, Lagos

ARTICLE HISTORY: received 21 December 2020; received in revised form 25 July 2021; accepted 9 August 2021

\section{Introduction}

Rapid urbanization, or urban sprawl, has been known to be one of the significant anthropogenic vectors of land cover and landscape change. Especially in the coastal regions with $80 \%$ of the world's biodiversity, this along with population explosion in the coastal belt, has become a significant environmental issue (AMOSU ET AL., 2009; UN-HABITAT,
2010). With a demographic shift to cities, the demand on land and the consumption of natural resources coupled with the ecological footprint to sustain ecological services for surging urban populations are increasing (FAULKNER, 2004; UN-HABITAT, 2010). Land cover changes resulting from these pressures for settlements and infrastructure lead to dramatic changes in both landscape patterns and ecosystem functions (TURNER, 1989; LUCK ET AL., 2001; HEROLD ET 
AL., 2003; HE \& YIN, 2010). The modification and conversion of large natural, or agricultural, areas to built-up areas, or uses associated with human settlements, can lead to loss of forests and wetlands, air quality impairment, increase in impervious surfaces, reduced aquifer recharge, flooding, ecosystem and landscape fragmentation, as well as biodiversity loss (FASONA ET AL., 2007; UN-HABITAT, 2010; SEIFolddini \& MANSOURIan, 2014). Further, changes in landscape patterns linked to urbanization are critical drivers of climatic and ecological changes at local, regional and even global levels (WENG ET AL., 2007). As a consequence, the capacity of natural ecosystems to perform intrinsic functions, both to society and the environment, is impaired when rapid and haphazard development occurs in areas of fragile environmental assets. Characterizing and quantifying the spatio-temporal changes in these environmental assets with urban expansion are potentially useful in tracking the capacity of these natural systems to continue to render those intrinsic ecological services to human systems (FLORES ET AL., 2008; SEIFOLDDINI \& MANSOURIAN, 2014). Consequently, analyzing and quantifying the landscape and land cover changes is useful when assessing the impact of these changes and articulating strategies for mitigation towards sustainable urban management. Increasingly, satellite imagery and remote sensing data along with GIS techniques, are providing accurate and timely means for tracking and studying land cover spatio-temporal trends to assess critical ecological processes in coastal ecosystems and at various scales (JENSEN, 2007; Olaleye ET AL., 2009; Klemas, 2011). These together with the development of landscape pattern indices, or metrics, (NONG ET AL., 2014) have provided practical ways to characterize these landscape trends for better appreciation of their ecological implications. According to WU ET AL. (2008), landscape metrics are perceived to be a component of the imperative techniques for understanding the function, structure and dynamics of landscapes and these are critical for solutions to a sustainable urban future. Equally, ONILUDE \& VAS (2020) suggest that landscape metrics can be used to understand the spatial pattern of land use/land cover change in an urban-rural context. To understand the changes in patterns and processes and their interactions in differing landscapes requires accurate quantification of the spatial pattern of those landscapes and their temporal fluxes (WU ET AL., 2000; WENG ET AL., 2007).

Lagos metropolis, the eighteenth largest urban agglomeration in the world in 2018, (UN-POPULATION DIVISION, 2018) and Lagos State are situated a few degrees north of the equator on a low-lying coastal plain of Nigeria, endowed with numerous lagoons and a single inlet from the Atlantic Ocean. Nigeria's coastal zone was known to be rich in ecology and biodiversity (FASONA ET AL., 2007). Rapid urbanization has seen the metropolis evolve historically from a pepper farm into a megacity, which approximates to 17 of the State's 20 local government areas (LGAs) and impinges imperceptibly on four local government areas of the adjoining Ogun State of Nigeria. The megacity area is geographically disjointed by a maze of islands/mainland and wetlands and is overwhelmed by its urbanization growth rate of $6-8 \%$. This growth has seen the population of the metropolis rise from about 5.7 million in 1991 to about 9.1 million in 2006 (NPC, 2006) with an average density of 20,000 persons $/ \mathrm{km}^{2}$ while it is being speculated to have grown to about 18 million by 2015 . Tied to this sprawl is the intense demand for land for development and infrastructure. Rapid and spontaneous development, sporadic reclamation of wetlands and floodplains coupled with wholesale deforestation (ABEGUNDE, 1988; ADELEKAN, 2009), have characterized the evolution of the metropolis and its movement into other parts of the state. For instance, TAIWO \& AREOLA (2009) observed an annual cumulative rate of wetland loss of $2.72 \mathrm{~km}^{2}$ or $0.6 \%$ from 1978 . By 2006, it was noted that these losses were occurring in previously safe rural areas. Within this period, there was the 1980-2000 Lagos State Regional Master Plan which was succeeded by the Revised Land Use Plan 2000/2001 and then by the Lagos State Regional Existing Land Use Plan 2002 which is the extant state planning document. Sustainable physical development and management of human settlements hinge largely on the effectiveness of the physical development plans (ODUWAYE, 2009) and more so on actions that ensure the faithful, judicious and realistic implementation of the plans. In this case however, these existing plans provided little methodological guidance for their actualization hence they were not followed (DAR AL-HANDASAH, 2009) as development occurred precipitously. Despite all these and spirited efforts by the current state authority to rein it in, development continues to leap-frog other development in all parts of the city and state. The western part, with its creeks and lagoon, constitutes about $39 \%$ of the state and has been transformed from a predominantly coastal, agrarian, landscape to one fractured by urban development.

In earlier studies in the eastern part of Lagos State (OBIEFUnA ET AL., 2013a, b) and within Lagos metropolis (OBIEFUNA ET AL., 2018), dramatic increases in built-up areas occurred in hitherto rural local council areas north-east and south-east of the metropolis where they replaced mostly ecological assets including wetlands and vegetation between 
1984 and 2006. For a synoptic view of the nature of landscape pattern changes state-wide, it became necessary to assess the western part of the state. The aim is still to establish the locations, magnitude and trend of the changes between 1984 and 2015 with a view to closing part of the information gap on the state-wide nature of landscape changes at local council levels. A further objective is to use landscape metrics to characterize the landscape pattern changes and its fragmentation effects on landscape structure. The significance of fragmentation of urban landscapes has become an issue confronting urban planners, policy makers and other stakeholders (ANGEL ET AL., 2010). While the mainland has a higher adaptive and resilient capability to cope with urban expansion, the littoral zone contends with the diverse challenges posed by the same phenomenon. For megacities located in low-lying coastal areas, coping with the threat of climate change as an added stressor to rapid population growth, makes achieving some of the pertinent Sustainable Development Goal (SDGs), a herculean task. The study is also in response to the call, and need, for more land cover change studies in Nigeria (ADEMILUYI ET AL., 2008) to guide proper land management and to aid solutions to problems associated with rapid urbanization.

\subsection{Theoretical background}

Since urban growth impacts on the form and structure of cities and consequently their functionality, resilience, and sustainability, the planning and management of urban spaces, therefore, requires a comprehensive knowledge of the development process and physical dimension of urban expansion (KLOSTERMAN, 1999). Universally, the level of urbanization is expected to rise to $67 \%$ by 2050 . By $2025,75 \%$ of the world's population is estimated to live within 60 kilometers of the sea, which can be considered "the global coastal zone," where more than $70 \%$ of the world's metropolises and megacities are located (UN, 2002). Urban expansion indicates the spatial, or physical, enlargement of built-up areas. This generally accompanies urban growth, but the dynamics of urban expansion also depend upon the nature of physical developments and the population densities they promote. Theoretically, the spatial evolution of cities can be described as a two-phase process of diffusion and coalescence (DIETZEL ET AL., 2005). The evolution of a city is observed to start with the expansion of an urban seed, or core area. As this seed grows, it diffuses to new urban centers, or cores. As the process of diffusion continues, it is paralleled by organic growth which leads to expansion away from existing urban areas and the infilling of gaps in between them.

As the urban system evolves, there comes a point at which the urban areas become so diffuse that they begin to coalesce towards a saturated urban landscape. The full build-out of the urban landscape can also be seen as a seed urban area for the hypothesized model to evolve at a coarser spatial scale. This process of 'scaling up' is similar to the concept found in traditional urban studies, whereby the spatial extent is changed through the use of concentric rings, or increasing distances, around a central urban core, or between urban centers (BLUMENFELD, 1954; LUCK \& WU, 2002). Spatial evolution of cities and expansion therefore starts with a historical seed, or core, that grows and disperses to new individual development centers. This process of diffusion continues along a trajectory of organic growth and outward expansion. However, a rapidly urbanizing population and associated urban growth will extend beyond its initial limits in the bid to accommodate the needs of its evolving status. Land cover change, as a consequence, is determined, in this case, by the interaction in space and time between biophysical and human influences. Its physical process is commonly described as either a change in absolute area of urban space (measure of extent), or the pace at which non-urban land is converted to urban uses (measure of rate). This extension, depending on the nature, be it sprawl, or controlled development, imperceptibly impinges upon hitherto natural landscapes, or environments, resulting in change in natural landcover and fragmentation.

In articulating the actual state of the urban fragmentation phenomenon, ANGEL ET AL. (2012, p. 249) opined that: "A key question that has confronted urban planners, policy makers and concerned environmentalists worldwide for some time is whether the fragmentation of the urban landscape is an inherent feature of contemporary cities that must be taken into account in planning for and managing urban expansion, or whether it is a disorderly, wasteful and undesirable form of sprawl that must be brought under control through containment or growth management strategies of one type or another".

Land cover change can, therefore, be an inevitable outcome of man - environment interactions, but rapid change with its attendant negative socioeconomic and environmental consequences can be overwhelming and irreversible. The implications of this on biodiversity and the livelihoods of those dependent on the resources of the landscape cannot be over-emphasized. Since changes on the surface of the earth are attributable to either natural, or 
anthropogenic forces, the directly human-induced conversion of land cover due to underlying forces of demographic, economic, technological, policy/ institutional and cultural, or socio-political, factors are of the most visible of global changes over the last three centuries. Landscape fragmentation, as the breaking up of larger areas of natural land cover into smaller, more isolated patches, independent of a change in the total area of natural land cover, has an important effect on ecosystem services, with a common assumption being that fragmentation reduces service provision. This is based on fragmentation's expected effects on ecosystem service supply, but ignores how fragmentation influences the flow of these services to people. MiTCHELL ET AL. (2015) argue that fragmentation's effects on ecosystem service flow can be positive, or negative. It, therefore, requires a conscious and deliberate effort to establish the critical limits at which fragmentation would become irreversibly detrimental and activities that would result in that. It is in the light of the above position of mixed implications that several studies emanating from diverse related fields have lent voices to the landscape break-up inquiries.

As such, the complexity of the urban fragmentation phenomenon, as a key feature in spatial/landscape structure investigation, requires a delicate approach within the context of spatial complexity. Fragmentation, as the division of habitat into smaller and more isolated fragments, separated by a matrix of human-transformed land cover, has become a key feature in spatial structure investigation. This is because the loss of area, increase in isolation, and greater exposure to human land uses along fragment edges initiate long-term changes to the structure and function of the remaining fragments. As inferred by DIDHAM ET AL. (2012), the ecologists agree that habitat destruction is detrimental to the maintenance of biodiversity, but they disagree strongly on the extent to which fragmentation itself is to blame. Central to the controversy has been a lingering uncertainty about the role of decreased fragment size and increased isolation relative to the widespread and pervasive effects of habitat loss in explaining declines in biodiversity and the degradation of ecosystems.

Ecological systems theory offers a framework through which individuals' relationships within communities and the wider society are examined. As a theory developed by BRONFENBRENNER (2005), it establishes the interconnectedness and mutual exclusivity of a closed system and the relationship between man and the environment over time, and the importance of other psychosocial, economic, cultural and environmental factors in influencing both the existence of man and the state of the environment. The harmonious coexistence between both parties largely lies on understanding the process of re-ordering, or re-configuring, of the environment through city formation.

Spatial metrics, as quantitative and aggregate measurements derived from digital analysis of thematic-categorical maps showing spatial heterogeneity at a specific scale and resolution (MCGARIGAl ET AL., 2002; HEROLD ET AL., 2003), generates fragmentation indices as a characterization of urban development providing an understanding of urban growth. The main idea is to learn the mechanism for the complex process of spatial urban growth by finding analogies and differences between a city's past development. A "landscape metric" is any scalar quantitative summary of landscape structure, being algorithms that quantify specific spatial characteristics of patches, classes of patches, or entire landscape mosaics. The two perspectives on categorical map patterns that profoundly influence the development of landscape metrics are Island Biogeographic and Landscape Mosaic Model and have implications for the choice and interpretation of individual metrics. Details of these two models are adequately covered in MCGARIGAL \& MARKS (1995) and MCGARIGAL ET AL. (2012).

In recent decades, urban studies have become increasingly concerned with urban fragmentation, referring to the morphological differentiation of pieces of urban land and their dispersal within urban space (CARSJENS \& VAN LIER, 2002; WEI \& ZHANG, 2012). GRAHAM \& MARVIN (2001) warn of the dangers of 'splintering urbanism', and BREMNER (2017) shows how archipelago spatiality can encourage social, economic, and legal fragmentation. Landscape fragmentation has been linked to several environmental consequences including physical effects (SAUNDERS ET AL., 1991) and biological effects such as a decline in biodiversity due to the loss and isolation of the habitat and/or species, (KuPFER \& FRANKLIN, 2009). While there are many quantitative measures for pattern (MCGARIGAL ET AL., 2012; SOILle \& VoGT, 2008; WICKHAM ET AL., 2010; VOGT, 2014) and connectivity (SAURA \& TORNÉ, 2009; SAURA ET AL., 2011), fragmentation is usually provided as a qualitative description for a specific species living in the landscape under study but a quantitative assessment of fragmentation will contribute to the understanding and interpretation of landscape dynamics. As fragmentation is the breaking up of a habitat, ecosystem, or land-use type into smaller parcels (FORMAN, 1995), geometric concepts such as connectivity, contagion, complexity 
and entropy can be tailored to quantify it. Quantifying the impact of human activities on landscapes can therefore facilitate landscape resource policies and risk assessment studies. TURNER ET AL. (1989) state that qualitative and quantitative changes in measurements across spatial scales will differ depending on how scale is defined. There is no single correct or optimal scale to describe spatial heterogeneity. Landscape metric values change with classification levels; therefore, it is important to select the most appropriate classification level for a given area. Therefore, universal and consistent class level metrics (WU, 2004) were used to determine the spatial structure of the study area because information accumulated at class level from patches does not exist at patch level. Landscape level metrics give information about the whole region without detailing class relations. Most metrics at the class level are derived from patch level attributes and integrated over all the patches of a particular class (BRADY \& KELLERMAN, 2005). According to TISCHENDORF (2001), the class-level landscape metrics are more effective in defining ecological processes.

\subsection{Study area}

The study area encompasses the western portion of the Lagos metropolis and State in Nigeria, West Africa (Fig. 1). Lagos State is located on the southwestern tip of Nigeria abutting the Atlantic Ocean. Created in May 1967, the state occupies an area of $3632 \mathrm{~km}^{2}$ of land and water and is home to Lagos metropolis. Lagos is a former federal capital and the current economic capital of Nigeria. Lagos metropolis is recognized as one of the mega-cities of the world with rapid population growth since 1970 (UN, 2014). The state has experienced unabated urban sprawl which has seen the metropolis grow into surrounding towns and villages to practically become a one-city state (OBIEFUNA ET AL., 2021).

The study area is approximately between $2^{\circ} 23^{\prime} \mathrm{E}$ and $2^{\circ} 41^{\prime} \mathrm{E}$, and between $6^{\circ} 21^{\prime} \mathrm{N}$ and $6^{\circ} 43^{\prime} \mathrm{N}$ while covering an area of about $1063.84 \mathrm{~km}^{2}$ of land and water. This constitutes about $39 \%$ of the state. On the west, it is bound by Benin Republic; on the north by Ogun State while to the south, it is bound by the Bight of Benin/Atlantic Ocean. Its creeks and lagoon are part of the barrier-lagoon complex which covers the entire coastline of Lagos State for about $200 \mathrm{~km}$ eastward from the Nigerian/ Benin Republic border in the west (IBE, 1988). These are comprised of Badagry Creek which is the longest, Port Novo Creek, Lighthouse Creek and Ologe Lagoon. All these connect to the Atlantic Ocean through the Commodore Channel which is the only inlet/outlet to the Lagos harbor and the only western connection to Lagos Lagoon on the east. Due to the high wave energy on the barrier-lagoon coastline and the lack of 'exoreic' rivers or streams, the beaches are erosive (IBE, 1988). The northern part of the study area is home to Lagos International Airport. Many of the industrial estates of the city including Ikeja, Ilupeju, Isolo, Iganmu, Apapa and Amuwo Odofin are located in this area just as the ports and a number of the older parts of the metropolis (including Surulere, Ikeja, Mushin and Ajegunle) are also in the area. Of the 20 Local Government Areas (LGAs) in the state, 11 are mostly in this area although small parts of Apapa and Amuwo Odofin form part of the eastern portion. The LGAs include Agege, Ajeromi Ifelodun, Alimosho, Amuwo Odofin, Badagry, Ifako Ijaiye, Ikeja, Mushin, Ojo, Oshodi-Isolo and Surulere.

The climate of the area, as applicable to the entire state, is controlled by two air masses namely: the tropical maritime and tropical continental air masses. The tropical maritime air mass is wet and originates from the Atlantic Ocean. The tropical continental air mass is dry, dusty and warm, and originates from the Sahara Desert. Generally, there are two seasons in the area: the wet/rainy season that lasts from April to October and the dry season that lasts from November to March.

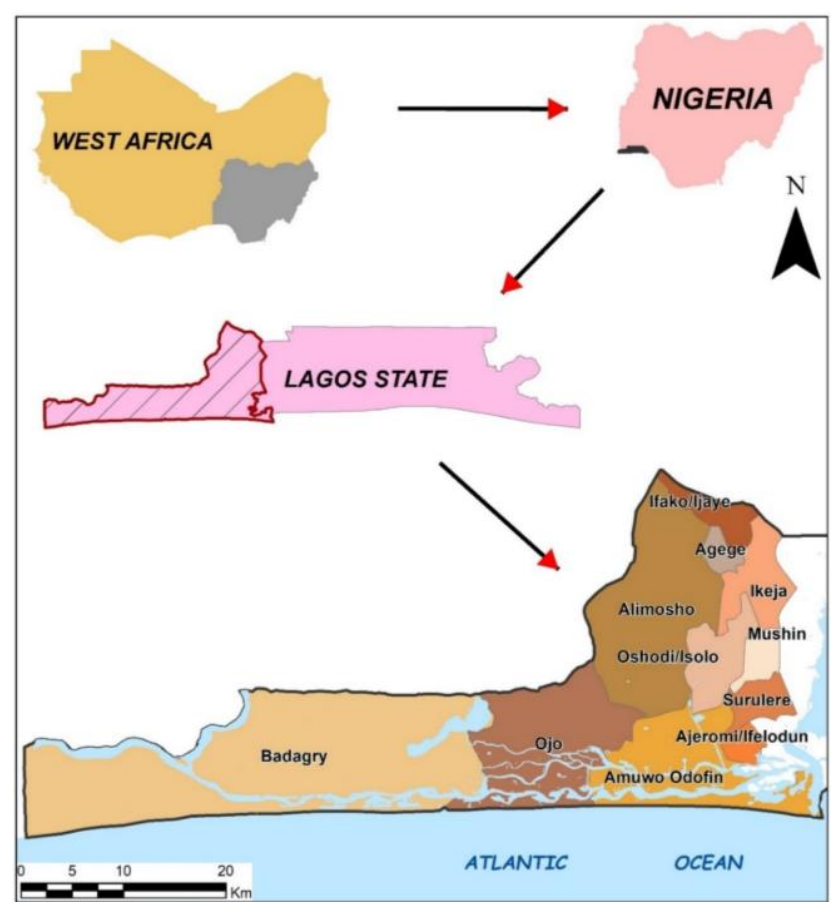

Fig. 1. Map of the study area 


\section{Materials and methods}

Three scenes of Landsat imagery, Thematic Mapper (TM) of December 1984, Enhanced Thematic Mapper (ETM+) of 2006 and Landsat 8 Operational Land Imager (OLI) of January 2015 were sourced from the United States Geological Surveys - Earth Resources and Observation (USGS EROS) Data Center. These imageries were processed with relevant baseline and ancillary data along with field reconnaissance. Using ENVI 5.0 software and unsupervised classification, six information classes of static land cover for the three dates were extracted. These land cover classes are: built-up area or urban development (including roads, buildings and urban infrastructure), bare land (including all cleared land for building, agriculture, sand mining and unpaved roads), vegetation (including forested and agricultural lands), water body, mangrove and swamp wetlands. The land cover classes were transferred to ArcGIS software (ESRI, 2021) for area calculation and preparation of land cover maps. An overlay of the 1984 and 2015 land cover maps produced the land cover change map. As a reflection of the urbanization pressure in the area, available 1991 and 2006 population figures for some LGAs were sourced from the National Population Commission (NPopC). Towards characterizing spatio-temporal changes and the effects of urbanization, the raster static land cover data for 1984 and 2015 at 30m pixel size were exported to the public domain FRAGSTATS v.4.2 which accepts ESRI ArcGrid format. FRAGSTATS is a software, or a spatial pattern analysis program, which computes a variety of landscape metrics for categorical map patterns (MCGARIGAL ET AL., 2012). Landscape metrics, as indicated by ZHANG ET AL. (2008) is one of the important avenues for understanding the dynamics, structure and functions of landscapes. In reality, landscapes are composed of complex spatial patterns of resources that vary temporally; the quantification of these patterns and dynamics falls within the scope of landscape pattern analysis (MCGARIGAL ET AL., 2012). Three landscape metrics were chosen for computation at class and landscape levels only for both dates (Table 1). These included area/edge metrics, shape metrics and diversity metrics. At the class level, metrics computed for area/edge metrics include class area (CA), percentage of landscape (PLAND), largest patch index (LPI) and mean patch size for the class (AREA_MN). For shape metrics at this level, indices computed include perimeter-area fractal dimension (PAFRAC), mean shape index (SHAPE_MN), area-weighted mean shape index (SHAPE_AM), mean contiguity index (CONTIG_MN) and areaweighted mean contiguity index (CONTIG_AM). With the exception of CA and PLAND, the total landscape area (TA) and the above indices along with Shannon diversity index (SHDI) were computed for the two dates at landscape-level. These metrics quantify the spatial patterns, or configuration, and structure of the entire landscape mosaic (MCGARIGAL ET AL., 2012).

Table 1. Description of landscape metrics computed for class and landscape levels (Source: McGarigal et al., 2012)

\begin{tabular}{|c|c|c|c|c|}
\hline Metric type & Level & Indices & Metric & Description \\
\hline \multirow[t]{4}{*}{ Area/edge } & \multirow[t]{4}{*}{$\begin{array}{c}\text { Class/ } \\
\text { Landscape }\end{array}$} & CA/TA & Class area/ Total area & $\begin{array}{l}\text { CA - measures total area of each patch or } \\
\text { class in hectares. } \\
\text { TA- total area in the landscape in hectares }\end{array}$ \\
\hline & & PLAND & $\begin{array}{l}\text { Percentage of landscape } \\
0<\text { PLAND } \leq 100\end{array}$ & $\begin{array}{l}\text { Quantifies the proportional abundance of } \\
\text { each class }\end{array}$ \\
\hline & & LPI & $\begin{array}{l}\text { Largest patch index } \\
0<\text { LPI } \leq 100\end{array}$ & $\begin{array}{l}\text { Measures the percentage of the landscape } \\
\text { occupied by the largest patch }\end{array}$ \\
\hline & & AREA_MN & Mean patch size & Portrays the average size of one class \\
\hline \multirow[t]{5}{*}{ Shape } & \multirow[t]{5}{*}{$\begin{array}{l}\text { Class/ } \\
\text { Landscape }\end{array}$} & PAFRAC & $\begin{array}{l}\text { Perimeter-area fractal dimension } \\
1 \leq \text { PAFRAC } \leq 2\end{array}$ & $\begin{array}{l}\text { Shape index based on perimeter- area } \\
\text { relationship; provides an index of shape } \\
\text { complexity for that patch/class }\end{array}$ \\
\hline & & SHAPE_MN & $\begin{array}{l}\text { Mean shape index } \\
\text { SHAPE } \geq 1 \text {, without limit }\end{array}$ & $\begin{array}{l}\text { Measure of average shape of a } \\
\text { patch/class }\end{array}$ \\
\hline & & SHAPE_AM & $\begin{array}{l}\text { Area-weighted mean shape } \\
\text { index }\end{array}$ & $\begin{array}{l}\text { Measure of average shape weighted with } \\
\text { area of coverage }\end{array}$ \\
\hline & & CONTIG_MN & $\begin{array}{l}\text { Mean contiguity index } \\
0 \leq \mathrm{CONTIG} \leq 1\end{array}$ & $\begin{array}{l}\text { Assesses the average spatial } \\
\text { connectedness, or contiguity of cells } \\
\text { within a patch/class }\end{array}$ \\
\hline & & CONTIG_AM & $\begin{array}{l}\text { Area-weighted mean contiguity } \\
\text { index }\end{array}$ & $\begin{array}{l}\text { Measure of average area-weighted } \\
\text { contiguity of cells }\end{array}$ \\
\hline Diversity & Landscape & SHDI & $\begin{array}{l}\text { Shannon diversity index; } \\
\text { SHDI } \geq 0\end{array}$ & $\begin{array}{l}\text { Quantifies diversity and composition at } \\
\text { landscape level at different times or } \\
\text { between landscapes }\end{array}$ \\
\hline
\end{tabular}




\section{Results and analysis}

\subsection{Land cover change analysis}

Figures 2, 3 and 4 present the land cover maps for 1984, 2006 and 2015 respectively. Similar to the eastern part of Lagos State, results show dramatic decreases in the natural landscape as wetlands were replaced by built-up areas or urban landscape although the aggregate coverage of wetlands is lower and vegetated landscape coverage is higher in this part. Figure 5 shows the percentage distribution of land cover for 1984, 2006 and 2015.
While swamps decreased from $145.7 \mathrm{~km}^{2}$ in 1984 to $88.9 \mathrm{~km}^{2}$ in 2006 at $-2.6 \mathrm{~km}^{2} \mathrm{yr}^{-1}$ to $47.5 \mathrm{~km}^{2}$ in 2015 at a faster rate of $-4.6 \mathrm{~km}^{2} \mathrm{yr}^{-1}$, mangroves decreased from $70.6 \mathrm{~km}^{2}$ to $28.9 \mathrm{~km}^{2}$ in 2006 at $1.89 \mathrm{~km}^{2} \mathrm{yr}^{-1}$ and down to $15.2 \mathrm{~km}^{2}$ in 2015 at 1.5 $\mathrm{km}^{2} \mathrm{yr}^{-1}$. Vegetation equally decreased from 586.4 $\mathrm{km}^{2}$ to $408.1 \mathrm{~km}^{2}$ at $-8.1 \mathrm{~km}^{2} \mathrm{yr}^{-1}$ between 1984 and 2006 and then to $294.7 \mathrm{~km}^{2}$ in 2015 at a higher rate of $-12.6 \mathrm{~km}^{2} \mathrm{yr}^{-1}$. Cumulatively, these ecological assets, which comprised about $75 \%$ of the landscape of the area in 1984, have more than halved to about $34 \%$ in 2015.

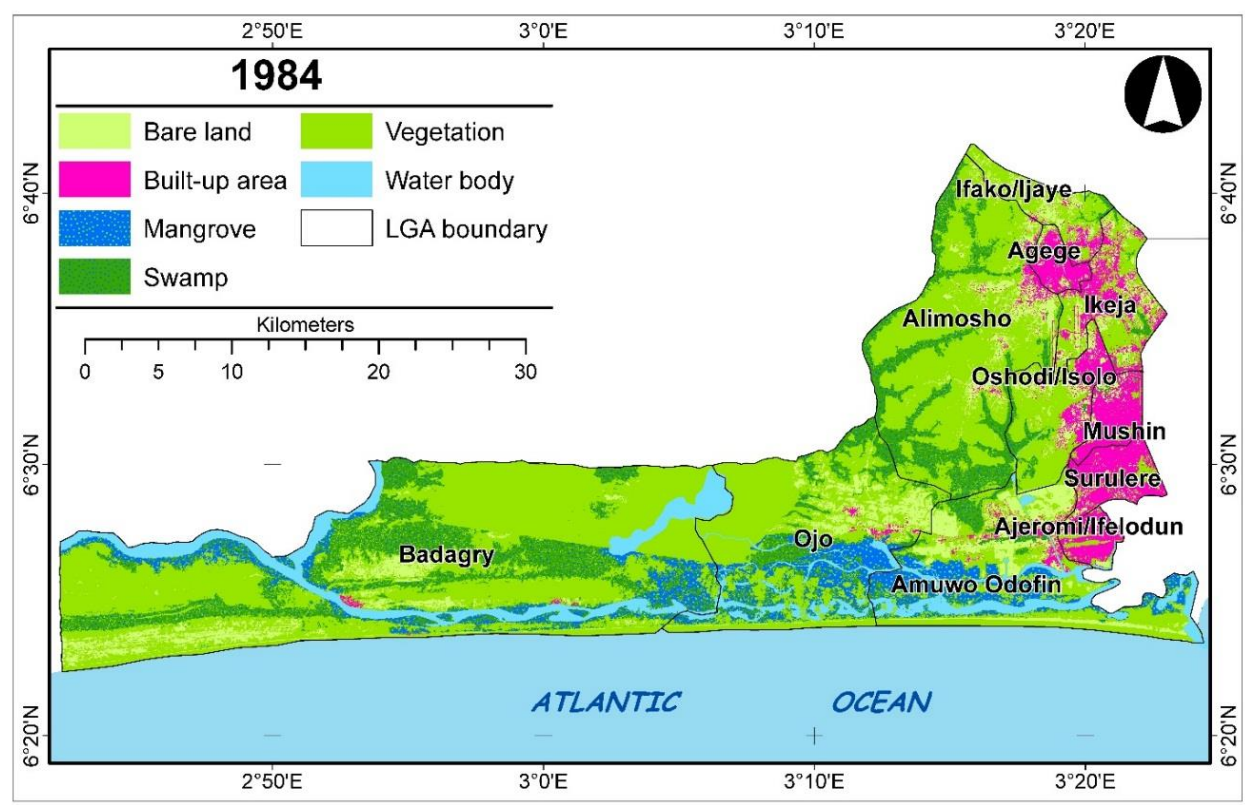

Fig. 2. Land cover map - 1984

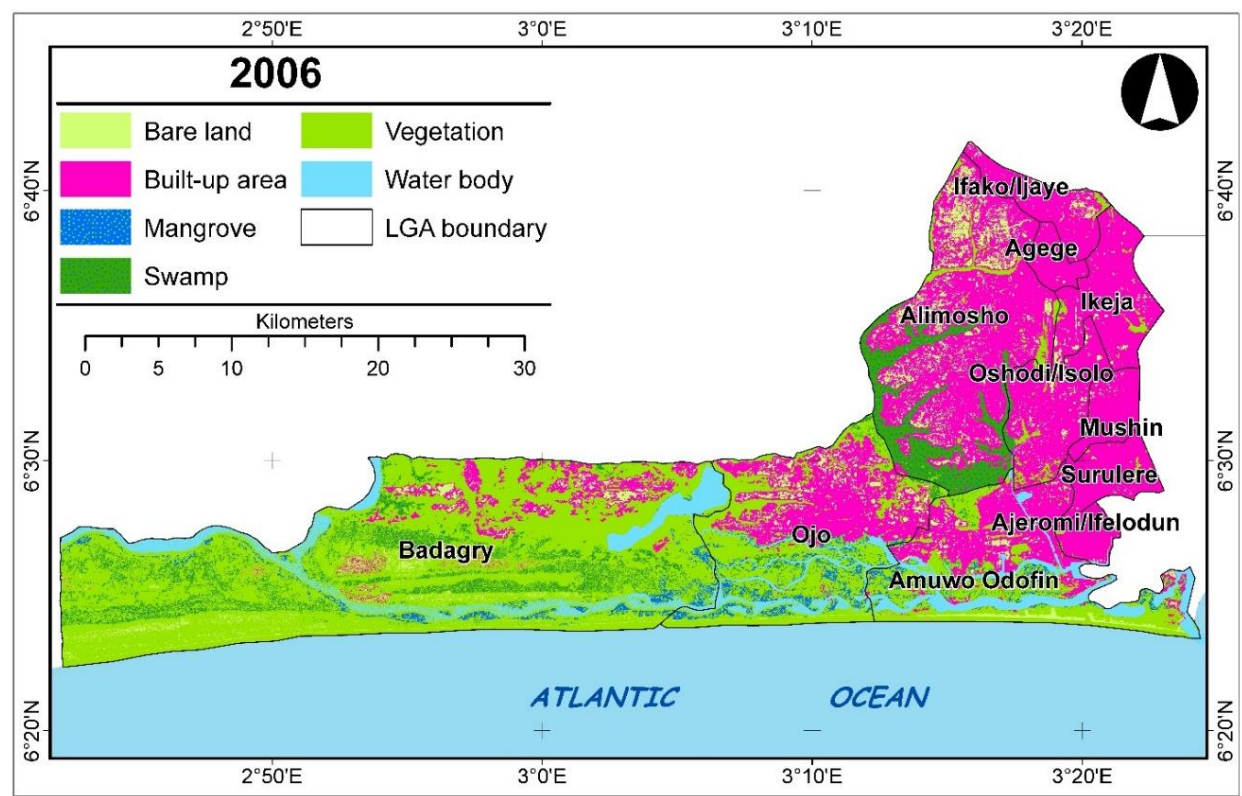

Fig. 3. Land cover map - 2006 


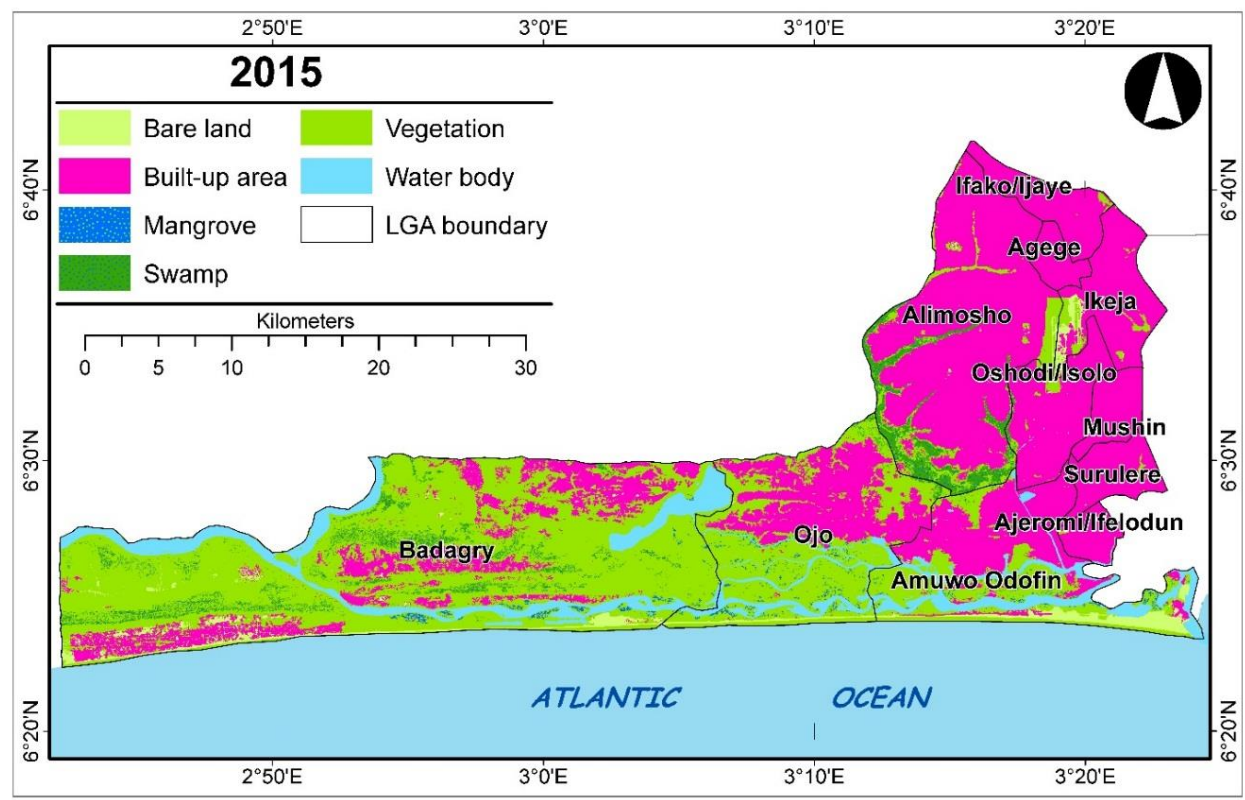

Fig. 4. Land cover map - 2015

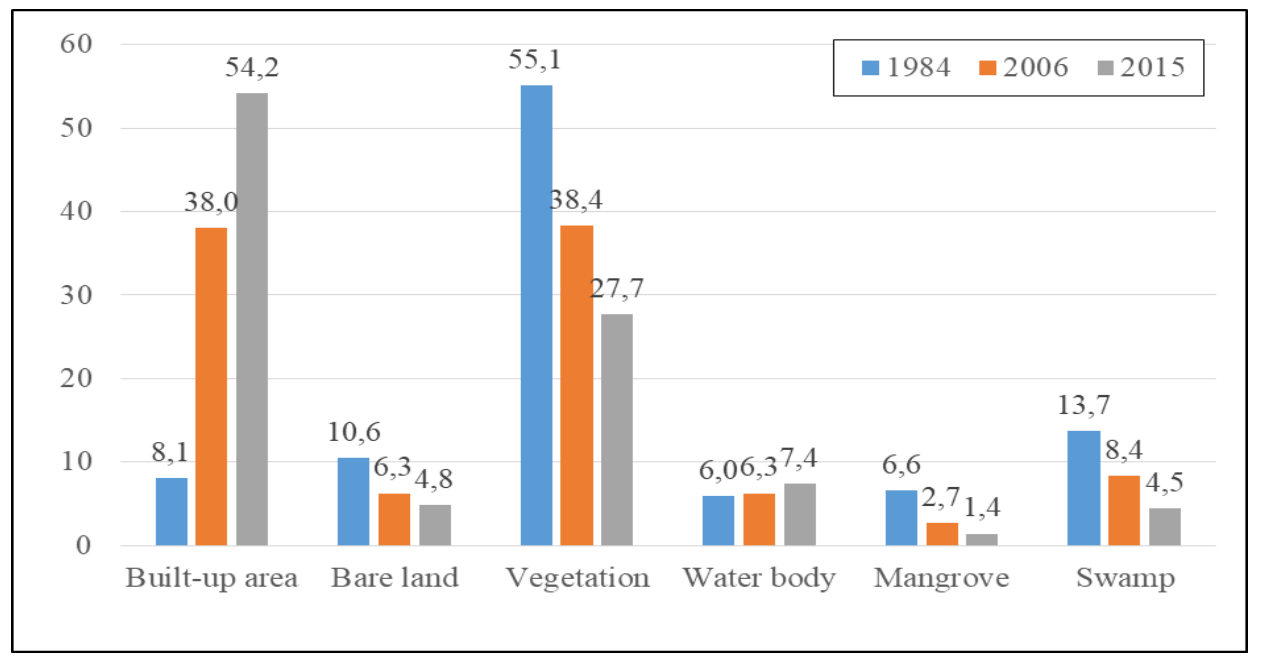

Fig. 5. Percentage distribution of land cover - 1984, 2006 and 2015

Figure 6 presents a map showing the pattern of expansion in built-up areas between 1984 and 2015 while the map in Figure 7 shows the transition of vegetation to built-up areas between 1984 and 2015. Bare land decreased from about $10 \%$ of the area in 1984 to just 5\% in 2015. Conversely, built-up area, or urban landscape, shot up from $85.6 \mathrm{~km}^{2}$ or $8 \%$ to $404.7 \mathrm{~km}^{2}$ at $14.5 \mathrm{~km}^{2} \mathrm{yr}^{-1}$ in 2006 and then to $576.9 \mathrm{~km}^{2}$ in 2015 at a higher rate of $19.1 \mathrm{~km}^{2} \mathrm{yr}^{-1}$. Clearly, vegetation, which occupied about $55 \%$ of the area in 1984 , had been supplanted by built-up area at about 54\% in 2015 (Fig. 7). The increase in water body, from $63.3 \mathrm{~km}^{2}$ to $78.2 \mathrm{~km}^{2}$ in the same period, can possibly be accounted for partly by the execution of the greater Lagos drainage works from the year 2000 onwards in six sub-catchments spanning eight local councils in this area.

When distributed in LGAs (Table 2), the results portray a clearer picture of locations and degree of changes that have occurred. In 1984, Surulere LGA was the most developed, or built-up, with $17.3 \mathrm{~km}^{2}$ followed by Ikeja and Mushin councils at $13.9 \mathrm{~km}^{2}$ and $13.6 \mathrm{~km}^{2}$ respectively. With increases in built-up areas in all the councils between 1984 and 2006, Alimosho LGA with a mere 5\% built-up initially grew fastest to about $28 \%$ or $112.7 \mathrm{~km}^{2}$ at the rate of $4.9 \mathrm{~km}^{2} \mathrm{yr}^{-1}$ in this period. This is followed by Ojo LGA which increased from $1.2 \mathrm{~km}^{2}$ to $52.5 \mathrm{~km}^{2}$ at $2.33 \mathrm{~km}^{2} \mathrm{yr}^{-1}$ while Amuwo-Odofin is next with an increase from $4.9 \mathrm{~km}^{2}$ to $49.5 \mathrm{~km}^{2}$ at the rate of $2.0 \mathrm{~km}^{2}$ yearly. In the same vein, Alimosho LGA maintained its lead as a growth area by increasing to $143.4 \mathrm{~km}^{2}$ built-up between 2006 and 2015 at a slightly lower rate of $3.4 \mathrm{~km}^{2}$ yearly. In this period too, Badagry LGA became the second growth area with $137.6 \mathrm{~km}^{2}$ at a whopping 12.4 $\mathrm{km}^{2} \mathrm{yr}^{-1}$ beating Ojo and Amuwo Odofin councils to third and fourth places at $70.3 \mathrm{~km}^{2}$ and $55.2 \mathrm{~km}^{2}$ respectively. The population figures of 1991 and 
2006 tend to mirror the growth in built-up areas in some of the local councils. For instance, the population of Alimosho LGA, the council with the highest built-up area increased by about $206 \%$ as its population increased from just over 430,000 in 1991 to slightly over 1.3 million in 2006 , a period of just 15 years. In the same manner, Ojo LGA with the second highest population, grew by about $182 \%$ between 1991 and 2006.

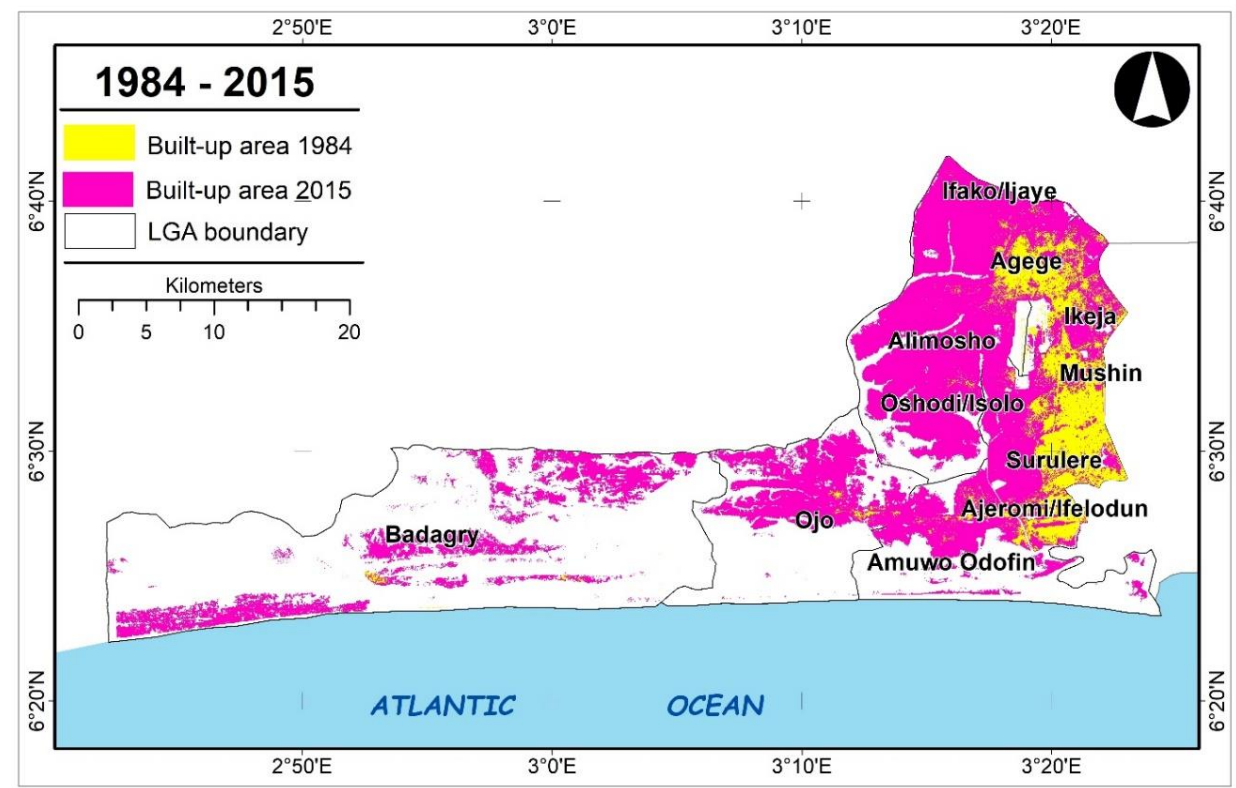

Fig. 6. Map showing pattern of expansion in built-up areas between 1984 and 2015

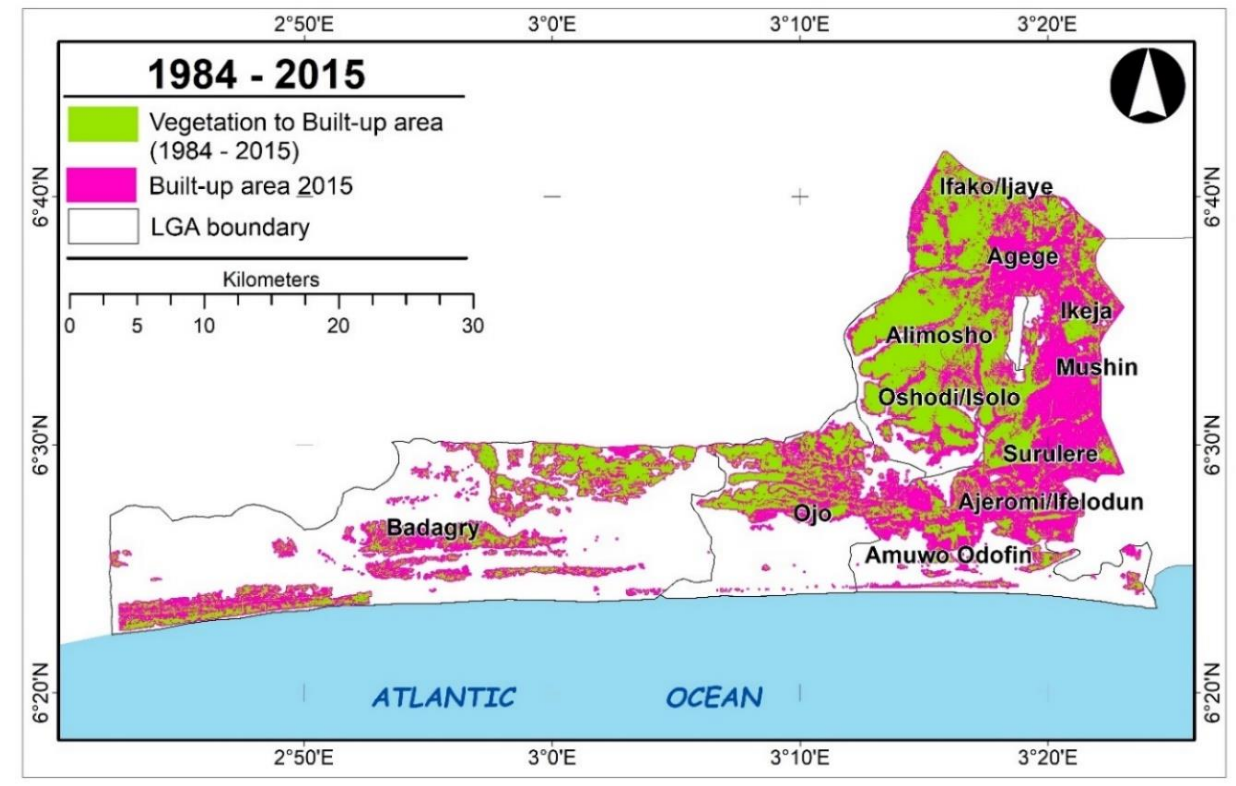

Fig. 7. Map showing transition from vegetation to built-up area between 1984 and 2015

In 1984, both Alimosho and Badagry councils had the most vegetated landscape in the study area with about $65 \%$ of the total. Similarly, at this time, three councils (Amuwo Odofin - 30\%, Badagry - 39\% and 0jo - 31\%) were hosts to all the mangrove wetlands of $70.57 \mathrm{~km}^{2}$, while four councils (Alimosho - 11\%, Amuwo Odofin - 6\%, Badagry - 70\% and 0jo - 11\%) hosted about $98 \%$ of the swamps in the area. Significantly, much of the urban growth in Alimosho Council occurred on vegetated landscape which experienced a sharp decline from $109.8 \mathrm{~km}^{2}$ to a mere $7.6 \mathrm{~km}^{2}$ at $-4.65 \mathrm{~km}^{2} \mathrm{yr}^{-1}$ between 1984 and
2006 and then to a paltry $2.3 \mathrm{~km}^{2}$ in 2015 . Swamps which occupied $16.6 \mathrm{~km}^{2}$ in this LGA in 1984 were completely decimated by 2006 at $-0.76 \mathrm{~km}^{2} \mathrm{yr}^{-1}$. In Ojo LGA, which was one of the three council areas (namely: Amuwo Odofin, Badagry and Ojo LGAs), where mangroves existed in the three periods, increases in built-up areas occurred at the expense of decreases in vegetated areas which went down from $90.0 \mathrm{~km}^{2}$ in 1984 to $66.4 \mathrm{~km}^{2}$ in 2006 at $-1.07 \mathrm{~km}^{2} \mathrm{yr}^{-1}$ and then to $57.3 \mathrm{~km}^{2}$ or $19.4 \%$ in 2015; mangroves decreased from $21.9 \mathrm{~km}^{2}$ to $12.0 \mathrm{~km}^{2}$ in 2006 at $-0.45 \mathrm{~km}^{2} \mathrm{yr}^{-1}$ and to $9.1 \mathrm{~km}^{2}$ 
or $59.6 \%$ in 2015 and swamps decreased from 16.4 to $4.3 \mathrm{~km}^{2}$ at $-0.55 \mathrm{~km}^{2} \mathrm{yr}-1$ between 1984 and 2006, and to $3.7 \mathrm{~km}^{2}$ or $7.7 \%$ in 2015 . Similarly, in Amuwo Odofin LGA, the increase in built-up area within the period occurred mostly on bare land which decreased from $23.0 \mathrm{~km}^{2}$ to
$5.8 \mathrm{~km}^{2}$ between 1984 and 2006 at $-0.8 \mathrm{~km}^{2} \mathrm{yr}^{-1}$ and to $2.6 \mathrm{~km}^{2}$ in 2015; mangroves reduced from $21.3 \mathrm{~km}^{2}$ to $5.6 \mathrm{~km}^{2}$ between 1984 and 2006 at $0.71 \mathrm{~km}^{2} \mathrm{yr}^{-1}$, then further went down to $3.4 \mathrm{~km}^{2}$ in 2015 while swamps which were annihilated by 2006 decreased from $8.5 \mathrm{~km}^{2}$ in 1984.

Table 2. Land cover distribution across LGAs - 1984, 2006 and 2015

\begin{tabular}{|c|c|c|c|c|c|c|c|c|c|c|c|c|}
\hline \multirow[t]{2}{*}{ LGA } & \multicolumn{2}{|c|}{$\mathrm{Bu}$} & \multicolumn{2}{|c|}{$\mathrm{Ba}$} & \multicolumn{2}{|c|}{ V } & \multicolumn{2}{|c|}{$\mathrm{W}$} & \multicolumn{2}{|c|}{$\mathrm{M}$} & \multicolumn{2}{|c|}{ S } \\
\hline & $\mathrm{km}^{2}$ & $\%$ & $\mathrm{~km}^{2}$ & $\%$ & $\mathrm{~km}^{2}$ & $\%$ & $\mathrm{~km}^{2}$ & $\%$ & $\mathrm{~km}^{2}$ & $\%$ & $\mathrm{~km}^{2}$ & $\%$ \\
\hline \multicolumn{13}{|c|}{1984} \\
\hline Alimosho & 4.1 & 4.8 & 16.8 & 15 & 109.8 & 18.7 & 0 & 0.1 & - & 0 & 16.6 & 11.4 \\
\hline Agege & 8.6 & 10 & 1.5 & 1.3 & 1 & 0.2 & - & 0 & 0 & 0 & - & 0 \\
\hline Ajeromi/Ifelodun & 8.4 & 9.8 & 0.6 & 0.5 & 3 & 0.5 & 0.3 & 0.5 & - & 0 & - & 0 \\
\hline Amuwo Odofin & 4.9 & 5.7 & 23 & 20.5 & 45.1 & 7.7 & 16.9 & 26.7 & 21.3 & 30.2 & 8.5 & 5.8 \\
\hline Badagry & 0.8 & 1 & 26.1 & 23.3 & 268.8 & 45.8 & 35.2 & 55.6 & 27.4 & 38.8 & 101.8 & 69.9 \\
\hline Ifako Ijaiye & 3.2 & 3.8 & 6.8 & 6 & 16 & 2.7 & 0 & 0 & 0 & 0 & 0.4 & 0.3 \\
\hline Ikeja & 13.9 & 16.3 & 10.9 & 9.7 & 20.5 & 3.5 & - & 0 & - & 0 & 0.5 & 0.4 \\
\hline Mushin & 13.6 & 15.9 & 1.7 & 1.5 & 2 & 0.3 & - & 0 & - & 0 & - & 0 \\
\hline Ojo & 1.2 & 1.4 & 16.2 & 14.5 & 90 & 15.3 & 10.8 & 17.1 & 21.9 & 31 & 16.4 & 11.3 \\
\hline Oshodi Isolo & 9.6 & 11.2 & 7.1 & 6.3 & 26.3 & 4.5 & - & 0 & - & 0 & 1.4 & 1 \\
\hline Surulere & 17.3 & 20.2 & 1.6 & 1.5 & 3.9 & 0.7 & - & 0 & - & 0 & 0 & 0 \\
\hline Total & 85.6 & 100 & 112.3 & 100 & 586.4 & 100 & 63.2 & 100 & 70.6 & 100 & 145.7 & 100 \\
\hline \multicolumn{13}{|c|}{2006} \\
\hline Alimosho & 112.7 & 27.8 & 27.2 & 40.7 & 7.6 & 1.9 & - & 0 & - & 0 & - & 0 \\
\hline Agege & 11 & 2.7 & 0.2 & 0.2 & - & 0 & - & 0 & - & 0 & - & 0 \\
\hline Ajeromi/Ifelodun & 11.5 & 2.8 & 0.1 & 0.1 & 0.4 & 0.1 & 0.3 & 0.4 & - & 0 & - & 0 \\
\hline Amuwo Odofin & 49.5 & 12.2 & 5.8 & 8.7 & 41.6 & 10.2 & 17.2 & 25.9 & 5.6 & 19.5 & - & 0 \\
\hline Badagry & 25.8 & 6.4 & 16.3 & 24.4 & 286.2 & 70.1 & 37.4 & 56.1 & 11.3 & 39.2 & 83.2 & 93.6 \\
\hline Ifako Ijaiye & 23.6 & 5.8 & 2 & 3 & 0.8 & 0.2 & - & 0 & - & 0 & 0 & 0 \\
\hline Ikeja & 41.5 & 10.2 & 2.4 & 3.6 & 1.9 & 0.5 & - & 0 & - & 0 & - & 0 \\
\hline Mushin & 16.9 & 4.2 & 0.4 & 0.6 & - & 0 & - & 0 & - & 0 & - & 0 \\
\hline Ojo & 52.5 & 13 & 9.7 & 14.5 & 66.4 & 16.3 & 11.6 & 17.4 & 12 & 41.4 & 4.3 & 4.9 \\
\hline Oshodi Isolo & 37.7 & 9.3 & 2.4 & 3.6 & 2.9 & 0.7 & 0.1 & 0.2 & - & 0 & 1.3 & 1.5 \\
\hline Surulere & 22.1 & 5.5 & 0.3 & 0.4 & 0.4 & 0.1 & - & 0 & - & 0 & - & 0 \\
\hline Total & 404.7 & 100 & 66.7 & 100 & 408.1 & 100 & 66.6 & 100 & 28.9 & 100 & 88.8 & 100 \\
\hline \multicolumn{13}{|c|}{2015} \\
\hline Alimosho & 143.4 & 24.9 & 1.6 & 3.2 & 2.3 & 0.8 & - & 0 & - & 0 & - & 0 \\
\hline Agege & 11 & 1.9 & 0.1 & 0.2 & - & 0 & - & 0 & - & 0 & - & 0 \\
\hline Ajeromi/Ifelodun & 11.8 & 2 & 0 & 0 & 0.3 & 0.1 & 0.2 & 0.2 & - & 0 & - & 0 \\
\hline Amuwo Odofin & 55.2 & 9.6 & 2.6 & 5 & 42.7 & 14.5 & 15.3 & 19.6 & 3.4 & 22 & 0.5 & 1.2 \\
\hline Badagry & 137.6 & 23.8 & 38.7 & 75.5 & 186.5 & 63.3 & 51.4 & 65.7 & 2.8 & 18.4 & 43.3 & 91.1 \\
\hline Ifako Ijaiye & 24.9 & 4.3 & 0.2 & 0.4 & 1.3 & 0.4 & - & 0 & - & 0 & - & 0 \\
\hline Ikeja & 42.7 & 7.4 & 1.9 & 3.6 & 1.2 & 0.4 & - & 0 & - & 0 & - & 0 \\
\hline Mushin & 17.3 & 3 & 0 & 0.1 & 0 & 0 & - & 0 & - & 0 & - & 0 \\
\hline Ojo & 70.3 & 12.2 & 4.8 & 9.4 & 57.3 & 19.4 & 11.3 & 14.4 & 9.1 & 59.6 & 3.7 & 7.7 \\
\hline Oshodi Isolo & 40.3 & 7 & 1.3 & 2.6 & 2.7 & 0.9 & 0 & 0 & - & 0 & - & 0 \\
\hline Surulere & 22.4 & 3.9 & - & 0 & 0.4 & 0.2 & - & 0 & - & 0 & - & 0 \\
\hline Total & 576.9 & 100 & 51.2 & 100 & 294.7 & 100 & 78.2 & 100 & 15.2 & 100 & 47.5 & 100 \\
\hline
\end{tabular}

$\mathrm{Bu}$ - Built-up area; Ba - Bare land; V - Vegetation; W - Water body; M - Mangrove; S - Swamp 


\subsection{Characterization with landscape metrics}

The class level metrics for both 1984 and 2015 (Table 3) in all respects do attest to the influence of rapid urbanization on the landscape structure of this area. In 1984, vegetation occupied the highest percentage of the landscape (PLAND) of about $55 \%$ as it covered over 58,000 ha. Water body occupied a very small percentage of the landscape with a PLAND of $7.06 \%$. The dominance of the landscape structure in this period by vegetation is reflected in it having the largest patch index (LPI) of 39.93\%; the second highest mean patch size (AREA_MN) of 86.89 ha after water body and a high shape complexity (PAFRAC) of 1.57. Also, it had the highest area-weighted mean shape index (SHAPE_AM) of 18.49 in addition to exhibiting the highest spatial connectedness or contiguity of cells in area-weighted contiguity index (CONTIG_AM) with 0.77 . Conversely, this dominance was taken over by built-up area or urban development in 2015 when it covered the most area (CA) and occupied the highest percentage of the landscape (PLAND) of $53.62 \%$ along with LPI of $39.60 \%$. In addition, it had the highest mean patch size (AREA_MN of 191.32 ha, low shape complexity (PAFRAC) of 1.51 and the highest connectedness or contiguity with CONTIG_AM of 0.87 . The fragmentation and decimation of some of the ecological assets of vegetation, including wetlands and mangroves in this period is further amplified by their respective PLAND, patch index (LPI), mean shape index (SHAPE_MN of 1.30, 1.20 and 1.0 respectively). Similarly, this is portrayed by their area-weighted mean shape index (SHAPE_AM) of 11.13, 3.90 and 1.0 respectively. Furthermore, their patch connectedness (CONTIG_AM) equally captures the situation with mangroves having zero contiguity of cells in 2015.

Table 3. Class level metrics - 1984 and 2015

\begin{tabular}{|c|c|c|c|c|c|c|}
\hline \multicolumn{7}{|c|}{1984} \\
\hline Class & $\mathrm{Ba}$ & $\mathrm{Bu}$ & V & W & S & M \\
\hline CA (ha) & 11315.10 & 8754.00 & 58564.80 & 7563.60 & 14023.80 & 7108.90 \\
\hline PLAND (\%) & 10.56 & 8.00 & 54.66 & 7.06 & 13.09 & 6.64 \\
\hline LPI (\%) & 1.82 & 4.69 & 39.93 & 3.52 & 4.51 & 1.81 \\
\hline AREA_MN (ha) & 18.89 & 37.45 & 86.89 & 112.89 & 28.68 & 32.02 \\
\hline PAFRAC & 1.60 & 1.59 & 1.57 & 1.49 & 1.61 & 1.56 \\
\hline SHAPE_MN & 1.28 & 1.23 & 1.30 & 1.47 & 1.32 & 1.43 \\
\hline SHAPE_AM & 4.83 & 8.04 & 18.49 & 5.84 & 9.09 & 4.73 \\
\hline CONTIG_MN & 0.14 & 0,11 & 0.13 & 0.21 & 0.13 & 0.19 \\
\hline CONTIG_AM & 0.51 & 0.70 & 0.77 & 0.76 & 0.57 & 0.59 \\
\hline \multicolumn{7}{|c|}{2015} \\
\hline CA (ha) & 5331.20 & 56630.30 & 31279.60 & 7745.90 & 4625.60 & 3.90 \\
\hline PLAND (\%) & 5.05 & 53.62 & 29.61 & 7.33 & 4.38 & 0.00 \\
\hline LPI (\%) & 0.63 & 39.60 & 11.04 & 5.09 & 1.18 & 0.00 \\
\hline AREA_MN (ha) & 9.14 & 191.32 & 51.03 & 119.17 & 14.37 & 1.96 \\
\hline PAFRAC & 1.56 & 1.51 & 1.55 & 1.51 & 1.55 & --- \\
\hline SHAPE_MN & 1.19 & 1.38 & 1.30 & 1.44 & 1.20 & 1.00 \\
\hline SHAPE_AM & 2.36 & 8.61 & 11.13 & 8.31 & 3.90 & 1.00 \\
\hline CONTIG_MN & 0.11 & 0.17 & 0.14 & 0.16 & 0.12 & 0.00 \\
\hline CONTIG_AM & 0.41 & 0.87 & 0.69 & 0.76 & 0.53 & 0.00 \\
\hline
\end{tabular}

The landscape level metrics (Table 4) affirms the class level results in confirming the dominance and fragmentation of ecological assets by urban development in 2015. The Largest Patch Index (LPI) as a spatial metric index quantifies compactness or degree of disaggregation. This landscape metric for the study area, over the period of consideration, represents the degree of a continuous patch in the landscape or the degree of brokenness into smaller patches with an increase of $2.67 \%$ over 3 decades. The consequence of this increase in fragmentation is an increase in isolation of class use with a negative implication for connectivity of landscape and proneness to further fragmentation. The trend of disaggregation therefore needs to be controlled. For the LPI of 39.60\% (which incidentally 
is the LPI of built-up area), a $19.5 \%$ increase in the mean patch size over that of 1984 and a decrease in PAFRAC to 1.54 all suggest a trend towards patches, or features with simple geometric shapes. PAFRAC approaches 1.0 (one) for shapes with very simple perimeters like squares but approaches 2.0 (two) for highly convoluted perimeters (MCGARIGAL ET AL., 2012). The decrease in shape complexity points to simple shapes symptomatic of anthropogenic forms such as urban development. Equally, the mean shape index (SHAPE_MN) shows a drop of 3\% in 2015. CONTIG_AM, Area-weighted mean contiguity index is a measure of spatial disaggregation. Low spatial contagion indicates highly fragmented landscapes. The degree of disaggregation of patches in a landscape represents disharmony in a system. A 0.07 increase in disaggregation for the period of study points to an increasing disintegration into splinters of the landscape system. The further disaggregation and evident fragmentation portend grave implications for the stability of the remaining ecosystem in the area. Disaggregation with sustained connectivity and network will ameliorate the possible effects of the landscape fragmentation.

Table 4. Landscape level metrics for 1984 and 2015

\begin{tabular}{|l|r|r|}
\hline \multicolumn{1}{|c|}{ Year } & \multicolumn{1}{c|}{1984} & \multicolumn{1}{c|}{2015} \\
\hline TA (ha) & 107151.20 & 105616.60 \\
\hline LPI (\%) & 36.93 & 39.60 \\
\hline AREA_MN (ha) & 47.00 & 56.15 \\
\hline PAFRAC & 1.58 & 1.54 \\
\hline SHAPE_MN & 1.31 & 1.27 \\
\hline SHAPE_AM & 13.18 & 8.82 \\
\hline CONTIG_MN & 0.14 & 0.13 \\
\hline CONTIG_AM & 0.70 & 0.77 \\
\hline SHDI & 1.40 & 1.17 \\
\hline
\end{tabular}

Above all, as low diversity in landscape composition is synonymous with high contiguity, the Shannon diversity index for the study area shows a 16\% drop in the values for this diversity index (SHDI) from 1.40 to 1.17 over 30 years further amplifies the reduction in diversity and a trend towards a dominance of one or few patch types. SHDI $=0$ when there is no diversity and the landscape contains only one patch type/class. It, however, increases when the number of different patches/classes increases (MCGARIGAL ET AL., 2012). Clearly, there was more diversity in the landscape in 1984.

\section{Drivers and impacts of the observed changes}

Emanating from these analyses and characterizations is the reality that rapid urbanization and urban sprawl, with their lack of adequate supporting infrastructure, are enduring problems of the Lagos metropolis and the study area. Urban sprawl has morphed Lagos metropolis into the entire state as a megacity in this western part just as previously observed in the eastern segment. For a more informed appreciation of the subject, Avis (2019) suggested that rapid urbanization, or rapid urban expansion, is a global trend as an increasing number of people live in cities while exerting pressure on existing urban infrastructure which, in some instances, struggle to cope with the increased demands of these urban residents. This rapid expansion and growth have resulted in urban and suburban sprawl which is seen as the unrestricted outward growth of housing, commercial development and transportation corridors. Urban sprawl as the outward spread of low-density mix of land uses and built-up areas towards the urban fringe, or the surrounding countryside, with uncontrolled urbanization, has become a major feature of both Nigerian cities and those of the developing countries (OLUJIMI, 2009; UJOH ET AL., 2010; ANIEKWE \& IGU, 2019). Unlike in the developed countries of Europe and America, a significant feature of rapid urbanization and sprawl in Nigeria, and many of the developing countries, is that rapid growth is occurring without appreciable industrial expansion (OLUJIMI, 2009). Although some researchers have characterized the features of urban sprawl in Nigerian cities with studies in Abuja and other cities (OlUJIMI, 2009; UJOH ET AL., 2010; AVIS, 2019; ANIEKWE \& IGU, 2019), BLOCH ET AL. (2015) and OLUjIMI, (2009) succinctly summarized some of these characteristics as follows:

a) Rapid urban expansion and sprawl have transformed contemporary Nigerian cities, including Lagos, into multifaceted, or polycentric, dynamic entities of often unordered assemblages of the traditional core area and adjoining planned residential, commercial and industrial zones. These entities grow into a variety of new, typically suburban peripheral areas in varied configurations and social realities containing a diverse range of economic functions and social activities. The urban fabric of Lagos metropolis, for example, incorporates multiple functional districts, congregating them into an increasingly polycentric structure in which various cores hold different functions (FILANI, 2009 cited in BLOCH ET AL., 2015);

b) Urban expansion often occurs on the fringes with constant redefinition of the urban edge, often not restricted to municipal limits but frequently spills over various Local Government Areas (LGAs) or even states as in the case of Lagos and Abuja in Nigeria; 
c) Land for urban development in Nigeria has often been available outside formal state regulatory frameworks (OWEI ET AL., 2008 cited in BLOCH ET AL., 2015) as mechanisms for land delivery to follow a physical expansion strategy were largely lacking. This situation in such a largely unregulated land market and strong population growth, led to the appearance of unplanned and dispersed urban development;

d) The economic forces behind the supply of land for commercial development within the city boundaries encourages the acquisition of cheaper land at the suburbs for residential property development where most of the parcels are not subjected to conventional design into layouts to seek planning approval. Even where such parcels are designed into layouts, most are not linked to others for accessibility;

e) Deriving from their constitutional roles and powers, state governments have emerged as key actors in the strategic spatial planning processes needed to manage the dynamics of the Nigerian urban expansion;

f) The development control measures put in place to control physical development citywide and the sprawling areas are largely ineffective partly due to lack of political will to implement those measures. (However, experience has shown that many of the private developers in the fringes are mostly unwilling to abide strictly by the rules of development control and are wont to compromise the enforcement officials where the opportunity arises);

g) Planning frameworks which holistically address spatial expansion are currently limited in Nigeria just as appropriate population projections to accurately estimate urban land needs are lacking in the country.

Equally, some of the drivers of this sprawl in Nigerian cities have been highlighted to include:

a) Rapid urban population growth fed by declining mortality and persistent high fertility in some areas;

b) Rural-urban migration, which in the case of Lagos, BLOCH ET AL. (2015) showed that the state ranked among the highest migrant destinations in the country in 2010;

c) Increases in social, economic and political status of city residents has led to the quest for land for various uses and thus contributing to sprawl;

d) Pricing out of low-income earners and migrants from the city housing market which compels them to settle, or seek for cheaper land for settlement, at the suburbs and urban fringes; and e) The speculative activities of land speculators and landowners on the urban fringe encourages urban sprawl.

Lagos metropolis and the study area epitomize many of the characteristics enumerated above. As a megacity, the characteristics of the study area also aligns with the observations of KÖTTER (2004) wherein megacities are characterized by very high dynamics in spatial and demographic growth, change of land use and consumption of land for settlement purposes which mostly take place in the absence of urban planning. The extension of cities, he intoned, is always in advance of urban planning and provision of public facilities. Furthermore, in many cases there is a lack of an efficient infrastructure for public and private transportation, for proper garbage removal, sewage systems and water supply. Most city-dwellers have no sanitation facilities and rainwater drainage systems are totally inadequate, a situation which entails consequences for the environment and public health. As a low-lying coastal city and state with minimal drainage heads, Lagos megacity is afflicted by some of these drawbacks, which typify such cites of the world.

Deriving from the UN (2018) Population Prospects indicates that Tokyo, Japan is currently the world's largest megacity with a population of 37 million people while Lagos, Nigeria, a notable fast-growing megacity, is projected to be home to over 30 million people by 2050, WATKINS (2019) explored some commonalities and differences between these two megacities to illuminate the effects of urbanism in the world. Although Tokyo and Lagos have distinctly different development patterns, resulting in social and environmental issues, he noted that they share many of the same land use challenges. Their common denominator is their sprawling footprints, but they differ in their approaches to integrating the sprawl into the megacity fabric. Tokyo dealt with urban sprawl from the 1950s by incorporating surrounding villages into one large, unplanned, decentralized metropolis while each neighborhood of the contiguous city maintained a local government while vital services like roads and sewage were slowly expanded to reach every neighborhood and slum. This decentralized city structure, he added, provided the impetus for the development of an extensive metropolitan railway system which extends far into Tokyo's urban area and has made cars less necessary for many residents. Lagos megacity is primarily served by roads and a large bus network, he intoned, which witnessed the unveiling of Africa's first Bus Rapid Transit corridor in 2008. It should be added that Lagos megacity, for its part, equally runs a polycentric 
or decentralized urban structure. Further details on these can be found at the website of Population Education (https://populationeducation.org/).

Even with the rapid urban expansion observed from the above analyses, planning for the cognate transportation infrastructure for efficient movement and commerce in the Lagos megacity, has at best been piecemeal. This partly stems from the lack of any recent guiding master plan for this area, the metropolis and the state beyond the earlier land use plans mentioned above. Although the earlier land use plans had little utilitarian effect, they contained provisions for light rail services of three arms to cover various parts of the metropolis, converging at Lagos Island (north) and designated as: (a) the 'Green Line' to cover the eastern segment of Lekki Peninsula and environs; (b) the 'Red Line' to cover the northern segment to Agbado; and (c) the 'Blue Line' to cover the western segment which is Lagos-Badagry expressway to Okokomaiko within the study area. All these were not implemented at the time. However, owing to persistent development pressure on transportation in this area and perhaps to the partial implementation of the earlier light rail proposals, the state a few years back embarked on a massive expansion of the 4-lane Badagry Expressway (a federal road and the main arterial route in this area) into a 10-lane carriageway with embedded light rail (Figures 8 and 9). Having progressed appreciably, this ambitious project seemingly has run into some headwinds thereby aggravating the hardships in traveling this route.

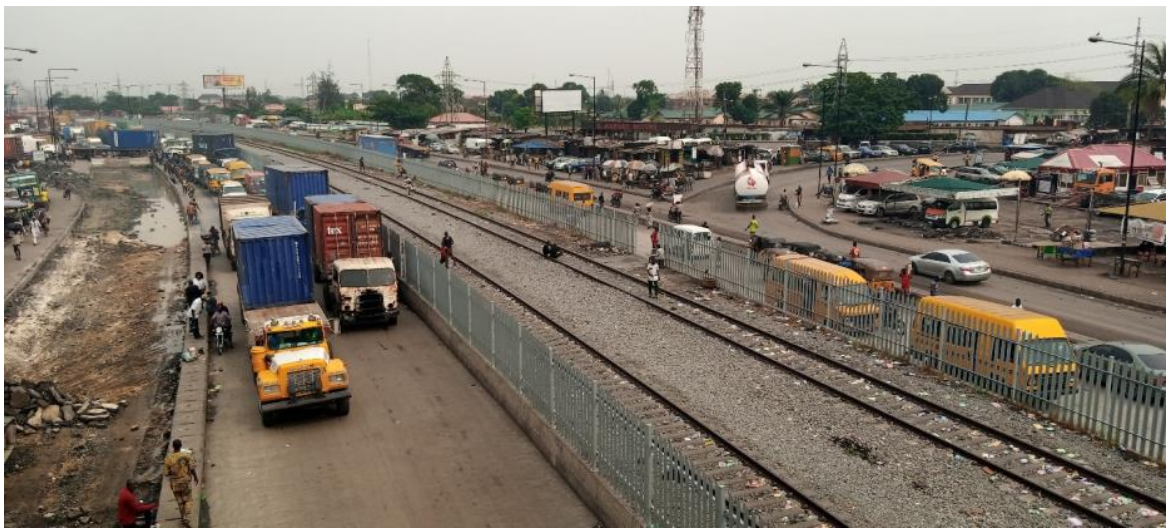

Fig. 8. Expansion of the Lagos-Badagry Expressway with embedded light rail at Mile 2 (Source: Field survey, 2020)

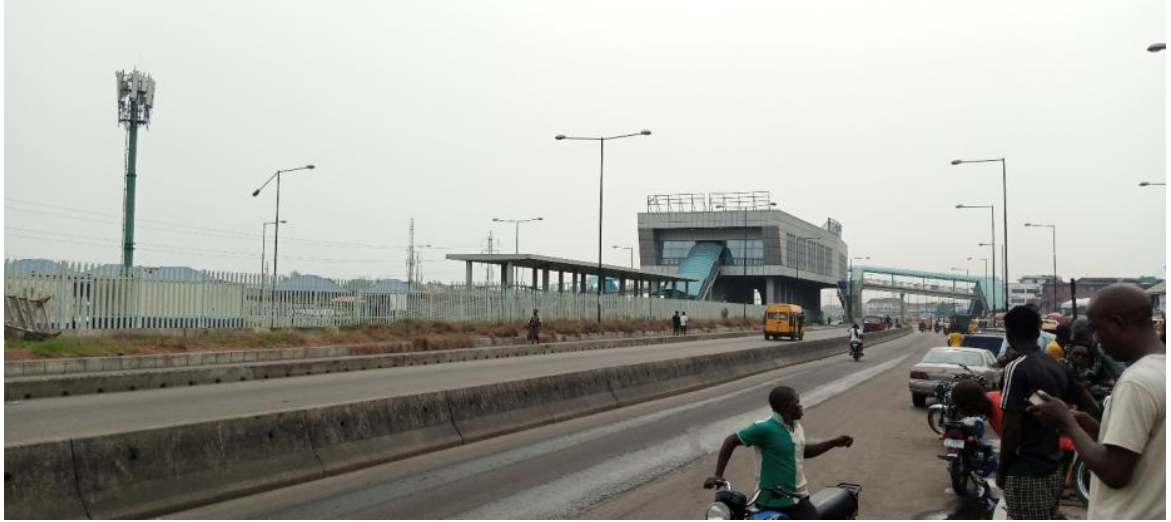

Fig. 9. Expansion of the Lagos-Badagry Expressway with embedded light rail at Orile (Source: Field survey, 2020)

Just like in the eastern part of Lagos State, the implication of the decimation of ecological assets of wetlands and mangroves is manifest in the loss of ecological services such as flood retention. The massive flooding from rains in the low-lying locations of this area possibly derives from the loss of these hitherto flood retention areas. In addition, the severe loss of vegetative cover and their replacement with impervious surfaces, can possibly contribute to flooding while potentially influencing outdoor thermal comfort. Concern for the latter has led to an investigation which is reported in OBIEFUNA ET AL. (2021).

\section{CONCLUSIONS}

The study has shown the structure, composition and spatio-temporal changes in the landscape of the study area. It has illustrated that in the base year of 1984, vegetation dominated the landscape 
at $55 \%$ coverage and as the largest patch, or feature, with the highest area-weighted contiguity or connectedness index. Thirty-one years later in 2015, it showed that built-up areas, or urban development, upstaged vegetation as the dominant patch with 54\% coverage and the highest contiguity and areaweighted contiguity index. At the local government level, it has also been pointed out that Alimosho LGA was the highest growth area followed by Badagry LGA with Ojo and Amuwo Odofin being the third and fourth growth areas. The growth in Alimosho LGA was supported by the growth in its population. Also, this growth in Alimosho LGA was shown to have occurred on vegetated landscape which diminished to $2.4 \mathrm{~km}^{2}$ in 2015 from 109.8 $\mathrm{km}^{2}$ initially. The only remaining mangroves in 2015 in highest order were identified to be in Ojo, Badagry and Amuwo Odofin LGAs just as the highest surviving swamps were in Badagry LGA.

The study has attempted to narrow the information gap on the spatial and temporal changes in the wetlands and ecological assets of the western segment of Lagos State occasioned by rapid urban expansion. Taken together with the earlier study on the eastern segment, they provide a synoptic view of the spatial and temporal changes on the landscape of the Barrier-Lagoon system of Lagos State. Emanating clearly from the study is the continued, unabated and unregulated urban expansion coupled with the fragmentation and decimation of some ecological assets. The rate at which these changes are taking place in the study area, it is reasonable to expect that the environmental damage may reach irreversible point before the need for reclamation is realized. Or, as observed in some former wetland areas of the Lagos Lagoon which were haphazardly developed, with settlement and sea-level rise, nature in due course may return to reclaim such low-lying wetlands equally haphazardly reclaimed and developed in this western segment.

A desirable recommendation from this study is the comprehensive management of both the remaining wetlands and green infrastructures towards maintaining some level of ecological services for the health of surging urban populations. This action expectedly should be underpinned by the up-to-date and accurate mapping of the study area and indeed the state. Although the Lagos State Enterprise GIS (LAGIS of 2009-2011) which involved Light Detection and Ranging (LiDAR) and Geographic Information Systems (GIS) mapping of the entire state was meant to have covered these, the online availability of such information currently is uncertain. Lamentably too, since the conservation of the remaining wetlands and mangrove areas was canvassed in OBIEFUNA ET AL. (2013b) and while the legal and institutional frameworks are still in place, no noticeable change in this effort has taken place at the local or state level. With the rapidly expanding megacity, the authorities constantly seem to have too much on their plate with disproportionately lower resources to match the expanding urban needs.

With the rapid urban expansion in the study area, an infrastructure issue such as potable water supply and water security are largely consigned to the whims and economic disposition of residents, hence the preponderance of hand-dug shallow wells. For considerations of public water supply, an area of further study is the assessment of the quantity and integrity of surface freshwater resources in this area through remote sensing and ancillary methods. Finally, a further basis for this study and future ones lies in echoing the call by ANIEKWE \& IGU (2019) that urban sprawl is dynamic; addressing it will require conscious and regular monitoring which is achievable through the measurement of its numerical magnitude and spread over time.

\section{Acknowledgements}

The authors are grateful to the FRAGSTATS Research and Development Team at Oregon State University and the University of Massachusetts Ecology Lab for the provision of FRAGSTATS; and the United States Government for free access to Landsat imagery through the USGS EROS Data Center. The assistance of Mr. Kingsley Iloduba in the acquisition of field pictures is acknowledged. This research was supported, in part, by a grant from the Central Research Committee (CRC), University of Lagos, Nigeria.

\section{References}

Abegunde M.A.A. 1988. Shoreline Erosion and Land Use Management on the Active Sandy Barrier Beaches around Lagos: A New Focus in Environmental Management. [in:] Sada P.O., Odemerho F.O. (eds) Environmental Issues and Management in Nigerian Development. Evans Brothers, Ibadan: 231-238.

Adelekan I.O. 2009. Vulnerability of Poor Urban Coastal Communities to Climate Change in Lagos, Nigeria. Paper presented at the Fifth Urban Research Symposium, Marseille, France, June 28-30, 2009.

Ademiluyi I.A., Okude A.S., Akanni C.O. 2008. An appraisal of landuse and landcover mapping in Nigeria. African Journal of Agricultural Research, 3,9: 581-586.

Amosu A.O., Bashorun O.W., Babalola O.O., Olowu R.A., Togunde K.A. 2012. Impact of climate change and anthropogenic activities on renewable coastal resources and biodiversity in Nigeria. Journal of Ecology and the Natural Environment, 4, 8: 201-211.

Angel S., Parent J., Civco D.L. 2010. The fragmentation of urban footprints: global evidence of sprawl 1990-2000, Lincoln Institute Working Paper, Lincoln Institute of Land Policy, Cambridge MA. available at http://www. lincolninst. edu/pubs/1835_The-Fragmentationof-Urban-Footprints 
Angel S., Parent J., Civco D.L. 2012. The fragmentation of urban landscapes: global evidence of a key attribute of the spatial structure of cities, 1990-2000. Environment \& Urbanization, 24, 1: 249-283.

Angel S., Parent J., Civco D.L., Blei A.M. 2011. The Atlas of Urban Expansion, The Lincoln Institute of Land Policy, Cambridge MA. available at http://www.lincolninst.edu/ publications/atlas

Aniekwe S., Igu N. 2019. A Geographical Analysis of Urban Sprawl in Abuja, Nigeria. Journal of Geographical Research, 2, 1: $13-19$

Avis W. 2019. Urban Expansion in Nigeria. K4D Helpdesk Report 692. Brighton, UK: Institute of Development Studies. K4D - Urban Expansion in Nigeria.

Bloch R., Fox S., Monroy J., Ojo A. 2015. Urbanisation and Urban Expansion in Nigeria. Urbanisation Research Nigeria (URN) Research Report. London: ICF International.

Blumenfeld H. 1954. The tidal wave of metropolitan expansion, Journal of the American Institute of Planners, 20: 3-14.

Brady M., Kellermann K. 2005. Methodology for Assessing the Regional Environmental Impacts of Decoupling: A Focus on Landscape Values; SLI-Working Paper, vol. 2; Swedish Institute for Food and Agricultural Economics: Lund, Sweden.

Bremner L. 2017. Observations on the concept of the aquapelago occasioned by researching the Maldives. Shima, 11, 1: 18-29.

Bronfenbrenner U. 2004. Ecological systems theory (1992). [in:] U. Bronfenbrenner (ed.) Making human beings human: Bioecological perspectives on human development. Sage Publications Ltd.: 106-173.

Carsjens G.J., van Lier H.N. 2002. Fragmentation and land-use planning: an introduction. Landscape and Urban Planning, 58, 2-4: 79-82.

Dar al-Handasah (Shair and Partners). 2009. Comprehensive Infrastructure Master Plan for Lekki Sub - Region, Lagos City - Nigeria. Final Master Plan Report. Ministry of Physical Planning \& Urban Development, Lagos State, Oct. 2009.

Didham R.K., Kapos V., Ewers R.M. 2012. Rethinking the conceptual foundations of habitat fragmentation research. Oikos, 121, 2: 161-170.

Dietzel C., Herold M., Hemphill J., Clarke K.C. 2005. Spatiotemporal dynamics in California's Central Valley: empirical links to urban theory, International Journal of Geographical Information Science, 19: 175-195.

ESRI 2021. ArcGIS overview. https://www.esri.com/enus/arcgis/about-arcgis/overview (Date accessed: 25 July, 2021)

Fasona M., Omojola A., Onyeahialam A. 2007. Mapping Land Degradation and Forest Resource Loss from Fused Landsat TM and Nigeria sat -1 Images in some parts of the Southwest Coast of Nigeria [in:] Owe M., Neale C. (eds) Proceeding of Symposium on Remote Sensing for Environmental Change Detection. IAHS Publication, 31, 110-118.

Faulkner S. 2004. Urbanization impacts on the structure and function of forested wetlands. Urban Ecosystems, 7: 89-106.

Filani M.O. 2011. A City in Transition: Vision, Reform, and Growth in Lagos, Nigeria, Cities Alliance.

Flores E.S., Olivas A.G., Chavez J. 2008. Land Cover Change and Landscape Dynamics in the Urbanizing Area of a Mexican Border City. ASPRS 2008 Annual Conference, Portland, Oregon.

Forman R.T.T. 1995. Some general principles of landscape and regional ecology. Landscape Ecology, 10: 133-142.

Graham S., Marvin S. 2001. Splintering urbanism: networked infrastructures, technological mobilities and the urban condition. Routledge, London.

He F., Yin J. 2010. Environmental Effects of Land Cover Change: Case Study of Coal Mining Areas in Beijing,
China. 18 $8^{\text {th }}$ International Conference on Geoinformatics, Beijing, China, 18 - 20 th June, 2010: 1-5.

Herold M., Goldstein N.C., Clarke K.C. 2003. The Spatiotemporal Form of Urban Growth: Measurement Analysis and Modelling. Remote Sensing of Environment, 86: 286-302.

Ibe A.C. 1988. Coastline Erosion in Nigeria. Ibadan University Press, Ibadan.

Jensen J.R. 2007. Remote Sensing of the Environment: An Earth Resource Perspective, $2^{\text {nd }}$ ed. Pearson Prentice Hall, Upper Saddle River, N.J. 07458.

Klemas V. 2011. Remote Sensing Techniques for Studying Coastal Ecosystems: An Overview. Journal of Coastal Research, 27, 1: 2-17.

Klosterman R.E. 1999. The what if? Collaborative planning support system, Environment and Planning B, 26: 393-408.

Kötter T. 2004. Risks and Opportunities of Urbanisation and Megacities. Paper presented at FIG Working Week 2004 Athens, Greece, May 22-27, 2004. PS2 Plenary Session 2 - Risk and Disaster Prevention and Management.

Kupfer J., Franklin S. 2009. Linking Spatial Pattern and Ecological Responses in Human-Modified Landscapes: The Effects of Deforestation and Forest Fragmentation on Biodiversity. Geography Compass, 3, 4: 1331-1355.

Luck M., Jenerette G., Jianguo W., Grimm N. 2001. The Urban Funnel Model and the Spatially Heterogonous Ecological Footprint. Ecosystems, 4, 8: 782-796.

Luck M., Wu J. 2002. A gradient analysis of urban landscape pattern: A case study from the phoenix metropolitan region, Arizona, USA. Landscape Ecology, 17: 327-339.

McGarigal K., Cushman S.A., Ene E. 2012. FRAGSTATS v4: Spatial Pattern Analysis Program for Categorical and Continuous Maps. Computer software program produced by the authors at the University of Massachusetts, Amherst. Available at: http://www.umass.edu/landeco/research/ fragstats/fragstats.html.

McGarigal K., Cushman S.A., Neel M.C., Ene E. 2002. FRAGSTATS: Spatial Pattern Analysis Program for Categorical Maps. Available at www.umass.edu/landeco/ research/fragstats/fragstats.html.

McGarigal K., Marks B.J. 1995. FRAGSTATS: Spatial pattern analysis program for quantifying landscape structure. USDA Forest Service General Technical Report PNW-351, Corvallis.

Mitchell M.G.E., Suarez-Castro A.F., Martinez-Harms M., Maron M., McAlpine C., Gaston K.J., Johansen K., Rhodes J.R. 2015. Reframing landscape fragmentation's effects on ecosystem services. Trends in Ecology \& Evolution, 30, 4: 190-198.

National Population Commission of Nigeria. 2006. The population of Local Government Areas (LGAs) of metropolitan Lagos (2006). Retrieved on 23/4/2015 from www.citypopulation. de/Nigeria-Lagos.html

Nong D., Lepczyk C., Miura T., Fox J., Spencer J., Chen Q. 2014. Quantify Spatiotemporal Patterns of Urban Growth in Hanoi Using Time Series Spatial Metrics and Urbanization Gradient Approach. East-West Center Working Papers. Environment, Population \& Health Series No. 2. Accessed on 14-1-2016 from: https://www.ciaonet.org/attachments/ 2669/uploads6

Obiefuna J.N., Nwilo P.C., Atagbaza A.O., Okolie C.J. 2013a. Land cover dynamics associated with the spatial changes in the wetlands of Lagos/Lekki Lagoon system of Lagos, Nigeria. Journal of Coastal Research, 29, 3: 671-679.

Obiefuna J.N., Nwilo P.C., Atagbaza A.O., Okolie C.J. 2013b. Spatial Changes in the Wetlands of Lagos/Lekki Lagoons of Lagos, Nigeria. Journal of Sustainable Development, 6, 7: $123-133$.

Obiefuna J.N., Nwilo P.C., Okolie C.J., Emmanuel E.I., Daramola O.E. 2018. Dynamics of Land Surface Temperature in 
response to Land Cover changes in Lagos Metropolis. Nigerian Journal of Environmental Sciences and Technology, 2, 2: 148-159.

Obiefuna J.N., Okolie C.J., Nwilo, P.C., Daramola O.E., Isiofia L.C. 2021. Potential influence of urban sprawl and changing land surface temperature on outdoor thermal comfort in Lagos State, Nigeria. Quaestiones Geographicae, 40, 1: 5-23.

Oduwaye L. 2009. Challenges of Sustainable Physical Planning and Development in Metropolitan Lagos. Journal of Sustainable Development, 21: 159-171.

Olaleye J.B., Abiodun O.E. and Igbokwe Q.C. 2009. Land Use Change Detection and Analysis Using Remotely Sensed Data in Lekki Peninsula Area of Lagos Nigeria. TS8B. SIM in Planning and Development, FIG Working Week 2009. Surveyors Key Role in Accelerated Development, Eliat, Israel, 3-8 May, 2009. Available at: www.fig.net/ pub/fig2009/papers/ts08b_olaleye_etal

Olujimi J. 2009. Evolving a Planning Strategy for Managing Urban Sprawl in Nigeria. Journal of Human Ecology, 25, 3: 201-208.

Onilude 0.0., Vaz, E. 2020. Data Analysis of Land Use Change and Urban and Rural Impacts in Lagos State, Nigeria. Data, 2020, 5: 72.

Owei E., Akarolo O. 2008. Land Market Distortions in Nigerian Cities and Urban Sprawl. 44th ISOCARP Congress, 2008.

Population Education. 2020. A program of population connection. Available at https://populationeducation.org/ [Date accessed: 29 May, 2021].

Saunders D., Hobbs R., Margules C. 1991. Biological Consequences of Ecosystem Fragmentation: A Review. Conservation Biology, $5,1: 18-32$.

Saura S., Torné J., 2009. Cone for Sensinode 2.2: A sofware package for quantifying the importance of habitat patches for landscape connectivity. Environmental Modelling and Sofware, 24: 135-139.

Seifolddini F., Mansourian H. 2014. Spatial-Temporal Pattern of Urban Growth in Tehran Megapole. Journal of Geography and Geology, 6, 1: 70-80.

Soille P., Vogt P. 2008. Morphological segmentation of binary patterns. Pattern Recognition Letters, 30, 4: 456-459.

Taiwo 0.J., Areola 0. 2009. A Spatial Temporal Analysis of Wetland Losses in the Lagos Coastal Region, south western Nigeria, using Multi-date satellite Imagery. Paper presented at IGARSS Annual Conference, Cape Town, South Africa, Sept. 2009.

Tischendorf L. 2001. Can landscape indices predict ecological processes consistently? Landscape Ecology, 16: 235-254.

Turner M.G. 1989. Landscape Ecology: The Effect of Pattern Process. Annual Review of Ecology and Systematics, 20: 171-97.

Turner M.G., O'Neill R.V., Gardner R.H., Milne B.T. 1989. Effects of changing spatial scale on the analysis of landscape pattern. Landscape Ecology, 3, 153-162.
Ujoh F., Kwabe I.D., Ifatimehin O.0. 2010. Understanding urban sprawl in the Federal Capital City, Abuja: Towards sustainable urbanization in Nigeria. Journal of Geography and Regional Planning, 3, 5: 106-113.

United Nations (UN) - Department of Economic and Social Affairs (UN-DESA), Population Division 2014. World Urbanization Prospects: The 2014 Revision. United Nations, New York.

United Nations (UN) - Department of Economic and Social Affairs (UN-DESA), Population Division. 2018. World Population Prospects: The 2018 Revision (ST/ESA/SERA/420). United Nations, New York.

United Nations (UN) - Habitat. 2010. Urban Development, Biodiversity and Wetland Management - Expert Workshop Report. Expert Workshop, 16-17 November, 2009. Kenya Wildlife Service Training Institute, Naivasha, Kenya. Bioscan (UK) Ltd, Oxford, UK.

United Nations (UN). 2002. World Population Prospects. The 2002 Revision. United Nations Population Division, New York.

United Nations Human Settlements Programme, UN-HABITAT. 2006. The State of the World's Cities Report 2006/2007, UN-Habitat, Nairobi, London.

Vogt P. 2014. GuidosToolbox (Graphical User Interface for the Description of image Objects and their Shapes): Digital image analysis software collection.

Watkins A. 2019. Examining Tokyo and Lagos: How Urbanization Looks in Megacities. Available at https://populationeducation. org/examining-tokyo-and-lagos-how-urbanization-looks-inmegacities/

Wei Y., Zhang Z. 2012. Assessing the fragmentation of construction land in urban areas: an index method and case study in Shunde, China. Land Use Policy, 29, 2: 417-428.

Weng Q., Hua L., Dengsheng L. 2007. Assessing the effects of land use and land cover patterns on thermal conditions using landscape metrics in city of Indianapolis, United States. Urban Ecosystems, 10: 203-219.

Wickham J.D., Stehman S.V., Fry J.A., Smith J.H., Homer C.G. 2010. Thematic accuracy of the NLCD 2001 land cover for the conterminous United States. Remote Sensing of Environment, 114, 6: 1286-1296.

$\mathrm{Wu}$ J. 2004. Effects of changing scale on landscape pattern analysis: Scaling relations. Landscape Ecology, 19:125-138.

Wu J. 2006. Landscape Ecology, cross-disciplinarity and sustainability science. Landscape Ecology, 21: 1-4.

Wu J., Jelinski D.E., Luck M., Tueller P.T. 2000. Multiscale analysis of landscape heterogeneity: scale variance and pattern metrics. Geographic Information Sciences, 6,1: 6-19.

Zhang Q., Yifang B., Jiyuang L., Quanquin S., Yunfewng H. 2008. Analysis of Landscape Dynamics in Shanghai using Landscape metrics: effects of spatial resolutions. The International Archives of the Photogrammetry, Remote Sensing and Spatial Information Sciences, Vol. XXXVII. Part B6b. 